\title{
Lactic Acidosis as a Result of Iron Deficiency
}

\author{
Clement A. Finch, Philip D. Gollnick, Michael P. Hlastala, Louise R. Miller, \\ Erick Dillmann, and Bruce Mackler, Department of Medicine, Divisions \\ of Hematology and Respiratory Diseases, Departments of Pediatrics and \\ the Center for Child Development and Mental Retardation, Department \\ of Physiology and Biophysics, University of Washington, Seattle, \\ Washington 98195; and Department of Physical Education, Washington State \\ University, Pullman, Washington 99164
}

A B S T RACT Iron-deficient rats have an impaired work performance, even when their anemia is corrected by exchange transfusion. Muscle activity is associated with a higher blood lactate concentration than is observed in iron-replete animals. The accumulation of lactate is a result of excessive production as lactate clearance from the blood was shown to be unaffected. By adjusting the work load to a lower level, it was possible to divide iron-deficient animals into two groups, one capable of continued treadmill rumning and another in which animals stopped before $20 \mathrm{~min}$. In the former, blood lactate concentration reached a plateau at moderate levels, whereas it continued to increase in the latter until the animal stopped running. Levels of $\alpha$-glycerophosphate oxidase in skeletal muscle mitochondria were found to be much lower in the second group $(P<0.001)$. Lactate infusion into normal animals was shown to interfere with work performance, and maintenance of a normal $\mathrm{pH}$ in iron-deficient and iron-replete animals did not prevent the impairment in work associated with high blood lactate concentrations. Additional evidence was obtained that energy substrate (blood glucose and free fatty acids, muscle glycogen) was adequate in irondeficient animals. Oxygen tension in their vena caval blood was higher than in controls. Furthermore, the in situ behavior of electrically stimulated gastrocnemius and soleus muscles appeared similar to that of control animals. Because the stimulation of the single muscle in the iron-deficient animal did not result in appreciable elevation of blood lactate and did not show impaired contractility further supported the hypothesis that the elevation of blood lactate caused the decreased work performance. It is concluded that iron deficiency by a depletion in the iron-containing mitochondrial enzyme, $\alpha$-glycerophosphate oxidase,

Received for publication 10 July 1978 and in revised form 12 February 1979. impairs glycolysis, resulting in excess lactate formation, which at high levels leads to cessation of physical activity.

\section{INTRODUCTION}

In a previous publication we have described an impaired rumning performance by iron-deficient rats (1). The effect of anemia was eliminated by adjusting the hemoglobin of iron-deficient and control animals to a uniform concentration of hemoglobin which permitted maximum work. Given parenteral iron, deficient animals regained a normal running ability within 3-4 $\mathrm{d}$. The cause of the running disability was believed to be a decrease in the mitochondrial enzyme system, $\alpha$-glycerophosphate oxidase. Evidence for this association was circumstantial, based on the similar time relationship between the depletion of this enzyme and its repletion with iron therapy and the impairment and recovery of work capacity. In this study further evidence is presented supporting the causal role of the $\alpha$-glycerophosphate oxidase system, and a metabolic explanation for the impaired work performance is provided.

\section{METHODS}

Male Sprague-Dawley rats were obtained at $4 \mathrm{wk}$ of age, 1 wk after weaning. Rats to be made iron deficient were given a low-iron diet prepared in our laboratory, ${ }^{1}$ which contained 5-10 mg iron $/ \mathrm{kg}$. By the end of the first month on this diet the hemoglobin concentration of those animals receiving it had fallen to $\cong 6 \mathrm{~g} / \mathrm{dl}$. The plasma iron and total iron binding capacity averaged $45 \pm 4.8^{2}$ and $850 \pm 15.5 \mu \mathrm{g} / \mathrm{dl}$ plasma, respectively. Two types of control animals were

\footnotetext{
${ }^{1}$ Made according to ICN Nutritional Biochemicals, Cleveland, Ohio.

${ }^{2}$ Throughout this article variations are expressed as standard error.
} 
employed. The first (type 1 control $[\mathrm{C} 1]^{3}$ was given Purina Laboratory Chow (Ralston Purina Co., St. Louis, Mo.) which contained $382 \mathrm{mg}$ iron $/ \mathrm{kg}$. The mean plasma iron (nonfasting) in this group of animals was $195 \pm 8 \mu \mathrm{g} / \mathrm{dl}$, and the iron binding capacity averaged $463 \pm 13.2 \mu \mathrm{g} / \mathrm{dl}$. Their mean hemoglobin before exchange transfusion was $14.2 \pm 0.14 \mathrm{~g} / \mathrm{dl}$. The second type of control animals (type 2 control [C2]) was given the iron-deficient diet described above but received weekly intraperitoneal injections of $5 \mathrm{mg}$ of iron dextran (Pharmacia Fine Chemicals, Div. of Pharmacia Inc., Piscataway, N. J.). The mean plasma iron and total iron binding capacity of these animals $1 \mathrm{wk}$ after the last iron injection was $142.8 \pm 12.3$ and $534.6 \pm 20.9 \mu \mathrm{g} / \mathrm{dl}$ plasma. Their mean hemoglobin concentration was $12.6 \pm 3 \mathrm{~g} / \mathrm{dl}$ blood. All animals were allowed to eat and drink ad libitum. Only those whose weights were between 200 and $250 \mathrm{~g}$ were used.

The protocol for the work performance studies included practice on the treadmill 7,6, and $5 \mathrm{~d}$ before the actual study, insertion of a vena caval catheter $4 \mathrm{~d}$ before, and an exchange transfusion carried out 1-4 h before the actual "run." Work performance was evaluated on a small animal treadmill as described elsewhere (1) (model 42-15, Quinton Instruments, Seattle, Wash.). Two different levels of work were employed. For the "fast run," the slope was initially set at $12.5^{\circ}$, and the belt was run at a speed of $18.76 \mathrm{~m} / \mathrm{min}$. As the animal ran, the slope but not the rate was increased (2). In the same animals, earlier training runs were carried out at rates of $13.4,16.16$, and $18.76 \mathrm{~m} / \mathrm{min}$ with the slope set at $12.5^{\circ}$ on successive days. For the "slow run" the slope was $0^{\circ}$, and a speed of $10.72 \mathrm{~m} / \mathrm{min}$ was used. Neither rate nor slope was changed at the time of the study. However, the training on days 7,6 , and 5 before the slow run study was carried out at a rate of $8.04,10.72$, and $10.72 \mathrm{~m} / \mathrm{min}$, respectively. The end point in the determination of running time in all experiments was that point at which the animal spent over $50 \%$ of the time on the electrically charged plate at the bottom of the running belt.

On the day of the study the hemoglobin of all animals was adjusted by exchange through the vena caval catheter of blood components freshly drawn from normal animals (anemic animals being exchanged with erythrocytes and normal animals with plasma) so as to achieve a common hemoglobin level of $\cong 10 \mathrm{~g} / \mathrm{dl}$ blood. Details of the catheter placement and exchange transfusion have been previously described (1).

To determine the effect of lactic acidosis, a $0.8-\mathrm{M}$ solution of $L$-lactic acid was infused intravenously in normal animals at a rate of $0.13 \mathrm{ml} / \mathrm{min}$; in other animals a $1.2-\mathrm{M}$ solution of sodium bicarbonate was infused intravenously at the same rate, either with or without simultaneous lactate infusion. The infusions were carried out through an inlying caval catheter while animals were exercising on the treadmill. $\mathrm{L}-\left[{ }^{14} \mathrm{C}\right]$ Lactate solution in tracer amounts was also injected into animals at rest to evaluate turnover. In all these studies blood samples were drawn from a second caval catheter distal to that of the catheter used for injection.

The use of inlying catheters permitted the removal of venous and arterial blood at a precise time, either in the resting animal or at the termination of exercise. Certain resting or exercising animals were killed by intravenous phenobarbital. As soon as they fell over, a leg was quickly skinned and the muscle frozen with tongs precooled in liquid nitrogen. The muscle was cut out and dropped into liquid nitrogen. It was then pulverized with a mortar and pestle precooled with liquid nitrogen and stored, frozen at $-60^{\circ} \mathrm{C}$. The freezing of the muscle was accomplished within

${ }^{3}$ Abbreviations used in this paper: $\mathrm{Cl}$, type 1 control(s); C2, type 2 control(s).
$0.6 \pm 0.04 \mathrm{~min}$ of the time the animal was anesthetized. In these studies muscle glycogen was determined by the methods of Passonneau and Lauderdale (3) and Lo et al. (4) whereas L-lactate was determined by the method of Hohorst (5).

$\alpha$-Glycerophosphate oxidase activity of the whole muscle was determined as follows: a $0.5-\mathrm{g}$ aliquot from the thigh muscles was placed in $3.5 \mathrm{ml}$ of a solution of $0.15 \mathrm{M}$ sucrose and $0.025 \mathrm{M}$ Tris, $\mathrm{pH} 7.5$, at $3-5^{\circ} \mathrm{C}$. The muscle was homogenized for $30 \mathrm{~s}$ with a Tekmar homogenizer (Tekmar Co., Cincinnati, Ohio). This was followed by homogenization over 3-5 min with a glass Teflon (E. I. Du Pont de Nemours \& Co., Inc., Wilmington, Del.) motor-driven homogenizer at full speed. A final homogenization was carried out by hand with a ground glass homogenizer to break up connective tissue clumps. The assays for enzymatic activity were carried out with a chamber volume of $1.75 \mathrm{ml}$ in an oxygen polarograph at $25^{\circ} \mathrm{C}$. The chamber contents included $1.12 \mathrm{ml}$ of a solution of $0.15 \mathrm{M}$ sucrose and $0.025 \mathrm{M}$ Tris, $\mathrm{pH} 7.5$, $0.1 \mathrm{ml}$ of $0.2 \mathrm{M}$ potassium phosphate buffer, $\mathrm{pH} 7.5$, and $0.5 \mathrm{ml}$ of muscle homogenate. After a constant blank rate of oxygen utilization was established, assays were begun by the addition of $0.03 \mathrm{ml}$ of $0.5 \mathrm{M} \alpha$-glycerophosphate.

Observations were made on an in situ preparation of the gastrocnemius and soleus muscles of normal and iron-deficient animals with equalized hemoglobin concentrations. The animals were prepared under anesthesia provided by intravenous injections of sodium pentobarbital. The muscles were isolated without disturbing the circulation. The leg was stabilized by drilling a hole through the femur and securing the drill bit in a steel holder on the board upon which the animals were mounted in a supine position. The ankle was fixed with the knee joint at a $90^{\circ}$ angle. The distal tendon of the muscle was looped through a brass ring, secured with a silk ligature, and connected directly to a Statham force transducer (Statham Instruments, Inc., Oxnard, Calif.). The nerve to the muscle was cut, and electrodes were fixed to the proximal and distal ends of the muscle. Muscle length was adjusted until a single stimulus evoked a maximal contraction. Stimuli of $14 \mathrm{~V}$ with a $0.76 \mathrm{~ms}$ duration were administered at $5 \mathrm{~Hz}$. Tension was monitored with a storage oscilloscope and recorded with a Beckman R611 polygraph (Beckman Instuments, Inc., Fullerton, Calif.). The body temperature of the animals was maintained at $37^{\circ} \mathrm{C}$ with a water-circulated heating pad. Mineral oil at $37^{\circ} \mathrm{C}$ was continuously dripped on the muscle. Blood samples were obtained from the indwelling catheter before and after stimulation. Samples of the rested and stimulated muscles were taken with the freeze clamp method (6). These were stored in dry ice until analyzed. Blood and muscle lactate, glucose, and glycerol were determined with fluorometric methods $(7,8)$.

Blood analyses included hemoglobin concentration by the cyanmethemoglobin technique and plasma iron and iron binding capacity as reported by The International Committee for Standardization in Hematology (9) and by Cook (10); glucose was determined by the oxidase method (Technicon Manual, Technicon Corp., Tarrytown, N. Y.); free fatty acids as described by Dole (11); and pyruvate and L-lactate by the methods of Hohorst (5) and Bücher et al. (12). The $\mathrm{P}_{50}{ }^{4}$ was determined by the mixing technique (13); and $\mathrm{PO}_{2}, \mathrm{PCO}_{2}$, and pH were measured with a microblood gas analyzer (Radiometer model BMS3, Radiometer Co., Copenhagen, Denmark). Base excess was determined from the Siggaard-Anderson Nomogram. Oxygen content was determined with a $\mathrm{LexO}_{2} \mathrm{Con}$ oxygen analyzer.

Statistical methods employed included the Student's

${ }^{4} \mathrm{P}_{50}$ is corrected to $\mathrm{pH}=7.4, \mathrm{PCO}_{2}=40$ torr, temperature $=37^{\circ} \mathrm{C}$. 
unpaired $t$ test and covariance analysis as described by Snedecor and Cochran (14).

\section{RESULTS}

Oxygen supply and gas exchange in the exercising iron-deficient animal. Studies were carried out on vena caval blood to determine the adequacy of oxygen supply. The $\mathrm{P}_{50}$ of eight iron-deficient animals whose hemoglobins had been adjusted $1-4 \mathrm{~h}$ before to $9.93 \pm 0.14 \mathrm{~g} / \mathrm{dl}$ was $39.4 \pm 1.1$ torr, whereas the corresponding values for eight $(\mathrm{Cl})$ controls with hemoglobins at $10.3 \pm 0.14 \mathrm{~g} / \mathrm{dl}$ was $39.2 \pm 0.6$ torr. Mean arterial $\mathrm{PO}_{2}$ before and immediately after a 2 -min fast run in six iron-deficient but nonanemic animals did not show any significant difference from control animals (Table I). However, the greater drop in $\mathrm{pH}$ observed in iron-deficient animals would result in a greater in vivo availability of oxygen during exercise. The mean arterial $\mathrm{PO}_{2}$ of resting animals, i.e., 69 and 72 torr, although they appear low, are consistent with previous reports in the literature $(15,16)$.

Measurements of vena caval blood gases in animals at rest and during exercise are also summarized in Table I. In the exercising iron-deficient group higher in vitro $\mathrm{PO}_{2}$ and lower $\mathrm{PCO}_{2}$ values as compared with

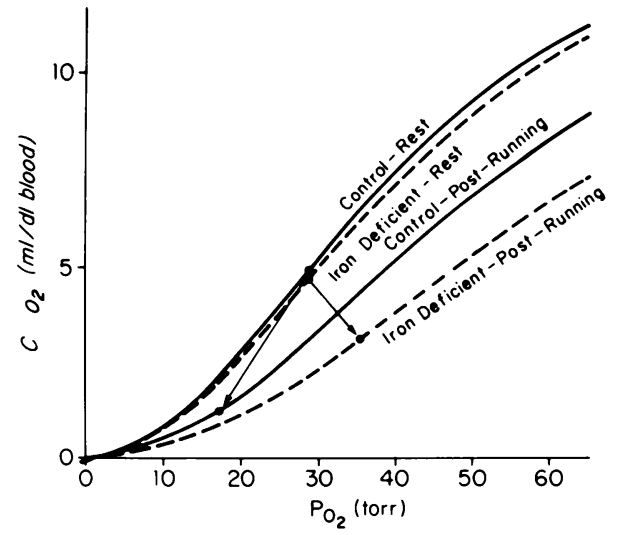

Figure $1 \mathrm{O}_{2}$ content $(\mathrm{C})$ of vena caval blood in resting and exercising animals. The $\mathrm{PO}_{2}$ values are corrected for in vivo conditions and are presumed to reflect average tissue oxygen tension.

control animals were demonstrated, as well as a higher concentration of blood lactate and a lower $\mathrm{pH}$. The base excess after exercise was lower in the irondeficient group because of the larger content of lactate in the blood. This resulted in a much higher in vivo venous $\mathrm{PO}_{2}$ because of the decrease in oxygen affinity (Fig. 1).

TABLE I

Blood Gases in Iron-Deficient and Control Animals before and after a 2-min Fast Run

\begin{tabular}{|c|c|c|c|c|}
\hline & \multicolumn{2}{|c|}{ Resting } & \multicolumn{2}{|c|}{ After 2 -min running } \\
\hline & Control & Iron-deficient & Control & Iron-deficient \\
\hline \multicolumn{5}{|l|}{ Arterial blood* } \\
\hline $\begin{array}{l}\text { Hemoglobin before exchange } \\
\text { transfusion, } g / d l\end{array}$ & $13.44 \pm 0.32$ & $5.52 \pm 0.19$ & & \\
\hline $\begin{array}{l}\text { Hemoglobin after exchange } \\
\text { transfusion, } g / d l\end{array}$ & $10.13 \pm 0.07$ & $9.79 \pm 0.07$ & & \\
\hline $\mathrm{PO}_{2}$, torr & $72.2 \pm 2.6$ & $68.9 \pm 1.1$ & $85.7 \pm 3.2$ & $85.6 \pm 1.8$ \\
\hline $\mathrm{PCO}_{2}$, torr & $36.6 \pm 2.1$ & $31.3 \pm 1.3$ & $26.4 \pm 1.6$ & $21.6 \pm 1.4 \S$ \\
\hline $\mathrm{pH}$ & $7.477 \pm 0.011$ & $7.443 \pm 0.020$ & $7.346 \pm 0.13$ & $7.138 \pm 0.032$ \\
\hline Lactate, $m M$ & $1.07 \pm 0.05$ & $1.04 \pm 0.13$ & $7.82 \pm 0.50$ & $15.3 \pm 1.8 \S$ \\
\hline Base excess, meg/liter & $+3.4 \pm 0.6$ & $-2.1 \pm 1.0 \$$ & $-10.1 \pm 1.0$ & $-20.9 \pm 1.0^{\prime \prime}$ \\
\hline $\mathrm{O}_{2}$ content, $\mathrm{ml} / \mathrm{dl}$ & $12.0 \pm 0.4$ & $11.8 \pm 0.18$ & $11.5 \pm 0.5$ & $11.3 \pm 0.3$ \\
\hline \multicolumn{5}{|l|}{ Vena caval blood $\ddagger$} \\
\hline $\begin{array}{l}\text { Hemoglobin before exchange } \\
\text { transfusion, } g / d l\end{array}$ & $14.80 \pm 1.10$ & $5.30 \pm 0.30$ & & \\
\hline $\begin{array}{l}\text { Hemoglobin after exchange } \\
\text { transfusion, g/dl }\end{array}$ & $9.90 \pm 0.10$ & $9.80 \pm 0.10$ & & \\
\hline $\mathrm{PO}_{2}$, torr & $28.70 \pm 1.20$ & $28.40 \pm 1.50$ & $17.10 \pm 2.50$ & $35.40 \pm 3.00^{\prime \prime}$ \\
\hline $\mathrm{PCO}_{2}$, torr & $39.40 \pm 0.08$ & $37.10 \pm 1.30$ & $47.30 \pm 1.80$ & $42.90 \pm 1.30$ \\
\hline $\mathrm{pH}$ & $7.46 \pm 0.01$ & $7.44 \pm 0.01$ & $7.18 \pm 0.03$ & $7.00 \pm 0.02^{\prime \prime}$ \\
\hline Lactate, $m M$ & $0.94 \pm 0.05$ & $2.24 \pm 0.49 \S$ & $10.90 \pm 1.30$ & $15.68 \pm 1.93$ \\
\hline Base excess, meq/liter & $+4.00 \pm 1.10$ & $+1.41 \pm 0.64$ & $-10.20 \pm 1.19$ & $-20.40 \pm 1.16^{\|}$ \\
\hline
\end{tabular}

* Six animals studied in each group.

$\$$ Eight animals studied in each group.

$\S$ Difference between iron-deficient and control animals significant to $P<0.05$.

"Difference between iron-deficient and control animals significant to $P<0.001$. 
A final study was carried out in which 12 exchangetransfused iron-deficient animals who were able to continue over $15 \mathrm{~min}$ of the slow run showed, at 15 min, a venous $\mathrm{PO}_{2}$ of $30.1 \pm 2.5$ torr and a mean venous $\mathrm{PCO}_{2}$ of $25.7 \pm 1.3$ torr. On the other hand, eight exchange-transfused iron-deficient animals who ran less than $15 \mathrm{~min}$, at the time they stopped running, showed a mean $\mathrm{PO}_{2}$ of $42.5 \pm 3.9$ torr and a mean $\mathrm{PCO}_{2}$ of $32.0 \pm 2.1$ torr. The differences between the two groups were significant $(P<0.05)$ for the $\mathrm{PCO}_{2}$ only.

Lactic acidosis. Additional studies of lactate and pyruvate concentrations after $2 \mathrm{~min}$ of the fast run are shown in Table II. Pyruvate levels were comparable in the two groups and did not change with exercise. On the other hand, blood lactate at rest was higher in the iron-deficient animals, and the difference was exaggerated with exercise, the lactate levels of irondeficient animals being about four times those of controls.

To examine the cause of the increased lactate concentration, L- $\left[{ }^{14} \mathrm{C}\right]$ lactate was injected in resting animals, and its disappearance curve is shown in Fig. 2A. Disappearance rates appear generally similar despite the larger blood lactate pool in the irondeficient animals. A comparison of lactate clearance was also made in animals during exercise. Here it was necessary to infuse lactate into normal animals immediately before running to achieve a lactate increase comparable to that seen in iron-deficient animals. Blood lactate concentration monitored during two successive 10-min periods after the animals stopped running is shown in Fig. 2B. Elevated blood lactate concentrations fell at least as rapidly and perhaps more so in iron-deficient as in control animals.

The excess accumulation of blood lactate could be shown more clearly when the work load was reduced to a point where some iron-deficient animals could run for prolonged periods. Under the condition of the slow run, normal animals ran easily for several hours with little increase in blood lactate concentration. At
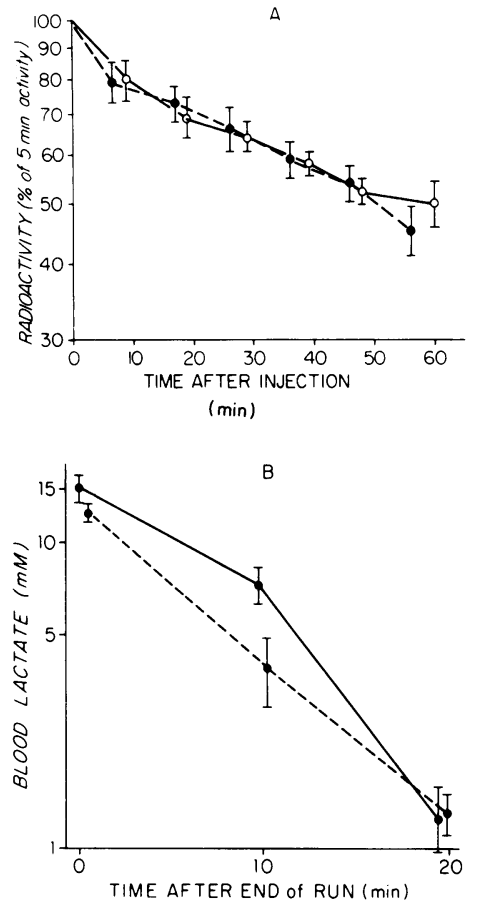

FIGURE 2 (A) The turnover of $\mathrm{L}-\left[{ }^{14} \mathrm{C}\right]$ lactate in resting rats. Each point represents an average of values in five animals. All points are expressed as a percentage of the activity in circulation at $5 \mathrm{~min}$. The initial disappearance rate in irondeficient animals (dashed line) is about one-half that of control animals (solid line). (B) The rate of decrease in plasma lactate beginning immediately after $2 \mathrm{~min}$ of the fast run. The normal animals (solid line) were infused with lactic acid before and during the run to achieve a similar blood lactate elevation. Vertical bars in both figures represent $\pm 1 \mathrm{SE}$.

$20 \mathrm{~min}$ their average lactate had increased from $0.77 \pm 0.05$ to $0.93 \pm 0.07 \mathrm{mM}$, and their initial $\mathrm{pH}$ of $7.46 \pm 0.01$ was unchanged. Under the same conditions, 12 of 27 iron-deficient animals with adjusted hemoglobins were able to run for only $6-12 \mathrm{~min}, 7$ animals

TABLE II

Blood Characteristics before and after a 2-min Fast Run*

\begin{tabular}{|c|c|c|c|c|}
\hline & \multicolumn{2}{|c|}{ Resting } & \multicolumn{2}{|c|}{ Exercised (2-min fast run) } \\
\hline & Controls $(\mathrm{Cl})$ & $\begin{array}{c}\text { Iron-deficient } \\
\text { diet }\end{array}$ & Controls (Cl) & $\begin{array}{l}\text { Iron-deficient } \\
\text { diet }\end{array}$ \\
\hline $\begin{array}{l}\text { Hemoglobin before transfusion, } \\
\text { g/dl whole blood }\end{array}$ & $13.90 \pm 0.20$ & $6.00 \pm 0.70$ & $14.50 \pm 0.50$ & $4.70 \pm 0.20$ \\
\hline $\begin{array}{l}\text { Hemoglobin concentration after exchange } \\
\text { transfusion, g/dl whole blood }\end{array}$ & $9.70 \pm 0.10$ & $10.10 \pm 0.10$ & $9.80 \pm 0.10$ & $9.80 \pm 0.10$ \\
\hline Lactate, $m M$ & $0.78 \pm 0.07$ & $1.76 \pm 0.16$ & $4.57 \pm 0.50$ & $18.35 \pm 1.38 \ddagger$ \\
\hline Pyruvate, $m M$ & $0.11 \pm 0.01$ & $0.19 \pm 0.02 \S$ & $0.30 \pm 0.03$ & $0.22 \pm 0.02$ \\
\hline
\end{tabular}

* Different groups of animals resting and exercised (6 animals).

$\$$ Difference between iron-deficient and control animals significant to $P<0.001$.

$\S$ Difference between iron-deficient and control animals significant to $P<0.05$. 
for $15 \mathrm{~min}$, and 8 ran for prolonged periods, well in excess of $20 \mathrm{~min}$ (Table III). Lactate levels were inversely proportional to running time. Most conspicuous was the progressive increase in lactate and depression in $\mathrm{pH}$ observed in those iron-deficient animals who were unable to run beyond $15 \mathrm{~min}$ (Fig. 3) as compared with either controls or iron-deficient animals who ran over $30 \mathrm{~min}(P<0.001)$.

The relationship of work performance to $\alpha$-glycerophosphate activity. The separation of exchangetransfused iron-deficient animals into two groups on the basis of their running ability permitted a further examination of the relationship between $\alpha$-glycerophosphate oxidase activity of muscle mitochondria and work capacity. Two groups of animals were identified. Group 1 consisted of animals who had been on an iron-deficient diet with a mean hemoglobin of $5.6 \pm 0.3$ $\mathrm{g} / \mathrm{dl}$ before exchange transfusion and who ran $15 \mathrm{~min}$ or less on the slow run. Group 2 consisted of iron-deficient animals with a mean hemoglobin of $5.5 \pm 0.4 \mathrm{~g} / \mathrm{dl}$ before exchange who ran more than $70 \mathrm{~min}$ on the slow run. Mean concentrations of the enzyme for the two groups are shown in Table IV. A highly significant difference in the $\alpha$-glycerophosphate oxidase activity between the two groups was found despite their identical deficit in circulating hemoglobin before the study.

Lactate vs. acidosis as a cause of work impairment. Data thus far suggested that tissue changes in iron deficiency, perhaps related to a decrease in $\alpha$-glycerophosphate oxidase activity resulted in a lactic acidosis and impairment of running. To determine whether lactic acid would produce this same reduction in running time in normal animals, L-lactate was infused for a period of $15 \mathrm{~min}$ at rest, and the infusion was continued during a fast run on the treadmill. A reduction in running time resulted at a mean lactate concentration of $18.4 \mathrm{mM}$, similar to the level reached in iron-deficient animals (Table V).

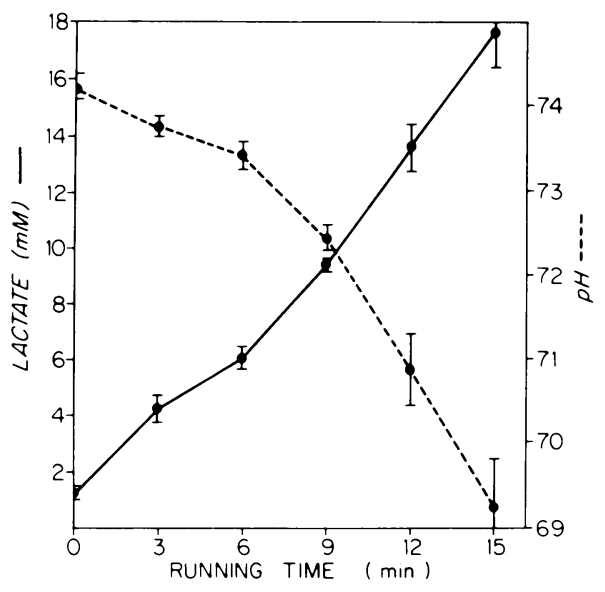

FIGURE 3 Changes in blood lactate and $\mathrm{pH}$ concentration in iron-deficient animals unable to run $20 \mathrm{~min}$ (slow run) are displayed. Each dot and vertical line represent the mean $\pm S E$ of values obtained in six animals. Normal animals run at the same rate had a mean plasma lactate of $0.8 \pm 0.2 \mathrm{mM}$ at $15 \mathrm{~min}$.

The increase in lactate was associated with a proportional decrease in $\mathrm{pH}$, so that it was not clear which was interfering with work performance. Accordingly, bicarbonate and lactate were simultaneously infused into normal rats during a fast run until they stopped running (Table V). Despite the maintenance of a normal venous blood $\mathrm{pH}$, a high blood lactate was associated with a marked reduction in running time. The higher lactate concentration reached by animals of group 2, infused with lactate at the same rate as animals of group 1, was presumed to be the effect of an arterial blood alkalosis. Iron-deficient animals who showed a marked increase in lactate during running but in whom the decrease in $\mathrm{pH}$ was prevented by a bicarbonate infusion also showed no improvement in work performance (Table VI).

Energy substrate. Although the increase in lactate rather than the acid $\mathrm{pH}$ seemed responsible for cessation

TABLE III

Vena Caval Blood Values Obtained at the End of a Slow Run Grouped According to the Work Performance of the Animals*

\begin{tabular}{|c|c|c|c|c|c|}
\hline Animals & $\begin{array}{c}\text { Number of } \\
\text { animals }\end{array}$ & $\begin{array}{l}\text { Hemoglobin } \\
\text { before exchange } \\
\text { transfusion }\end{array}$ & $\begin{array}{l}\text { Hemoglobin } \\
\text { after exchange } \\
\text { transfusion }\end{array}$ & $\mathrm{pH}$ & Lactate \\
\hline & \multicolumn{4}{|c|}{$g / d l$} & $m .11$ \\
\hline Controls (C2) & 10 & $12.0 \pm 0.3$ & $10.1 \pm 0.1$ & $7.46 \pm 0.012$ & $0.93 \pm 0.07$ \\
\hline Iron-deficient ( $\operatorname{ran}<15 \min )$ & 12 & $5.0 \pm 0.2$ & $9.9 \pm 0.1$ & $6.96 \pm 0.030 \$$ & $16.20 \pm 0.83 \ddagger$ \\
\hline Iron-deficient (ran $15 \mathrm{~min})$ & 7 & $5.0 \pm 0.3$ & $9.8 \pm 0.1$ & $6.93 \pm 0.050$ & $17.40 \pm 1.00 \ddagger$ \\
\hline Iron-deficient ( $\operatorname{ran}>15 \min )$ & 8 & $5.4 \pm 0.2$ & $9.9 \pm 0.1$ & $7.36 \pm 0.030$ & $3.70 \pm 0.80$ \\
\hline
\end{tabular}

* Animals which stopped running before $15 \mathrm{~min}$ were sampled through the inlying catheter at the time they stopped; animals running longer were sampled at $15 \mathrm{~min}$ while they were running.

$\ddagger$ Difference between iron-deficient and control animals significant to $P<0.001$. 
TABLE IV

$\alpha$-Glycerophosphate Oxidase Activity in Control and Iron-Deficient Rats Segregated According to Running Ability

\begin{tabular}{lcccc}
\hline \multicolumn{1}{c}{ Animals } & $\begin{array}{c}\text { Number of } \\
\text { animals }\end{array}$ & $\begin{array}{c}\text { Running } \\
\text { time }\end{array}$ & $\begin{array}{c}\text { Specific } \\
\text { activity* }\end{array}$ & $\begin{array}{c}\text { Total } \\
\text { activity }\end{array}$ \\
\hline & & $\min$ \\
Control $(\mathrm{Cl})$ & 5 & $>30$ & $0.0032 \pm 0.0003$ & $0.60 \pm 0.01$ \\
Iron-deficient (good runners) & 5 & $>30$ & $0.0025 \pm 0.0001 \S$ & $0.45 \pm 0.03$ \\
Iron-deficient (poor runners) & 5 & $9-19$ & $0.0011 \pm 0.0000^{\prime \prime}$ & $0.20 \pm 0.00^{\prime \prime}$ \\
\hline
\end{tabular}

* Specific activity $=\mu \mathrm{mol} \alpha$-glycerophosphate oxidized $/ \mathrm{min}$ per $\mathrm{mg}$ protein.

$\ddagger$ Total activity $=\mu \mathrm{mol} \alpha$-glycerophosphate oxidized/min per $\mathrm{g}$ tissue.

\$ Difference between iron-deficient and control animals significant to $P<0.05$.

"Difference between iron-deficient and control animals significant to $P<0.001$.

of activity, it was also desirable to establish that energy substrate was adequate. To examine this, blood from animals running 2 min under conditions of the fast run was examined. The mean plasma glucose of six irondeficient animals whose original hemoglobin of $5.6 \mathrm{~g}$ had been increased to $10.0 \mathrm{~g} / \mathrm{dl}$ blood was $8.7 \pm 0.6 \mathrm{mM}$ as compared with $10.4 \pm 0.5$ in six $\mathrm{Cl}$ animals who had also been exchange transfused. Although the difference was significant $(P<0.05)$, the glucose concentration of iron-deficient animals appeared adequate. Corresponding mean values for free fatty acids of 12 iron-deficient animals was $335 \pm 29 \mu \mathrm{eq} / \mathrm{liter}$ and for 12 control animals was $376 \pm 46 \mu \mathrm{eq} / \mathrm{liter}$ $(P>0.05)$. The glycogen content of thigh muscles in six iron-deficient exchange-transfused animals exercised for $2 \mathrm{~min}$ by the fast run was $29.8 \pm 4.1$ as compared with $\mathrm{Cl}$ values of $32.1 \pm 2.1 \mathrm{~g} / 100 \mathrm{mM}$ of glucose $\mathrm{U} / \mathrm{kg}$ wet muscle tissue $(P>0.05)$.

In situ studies of muscle function. Electrical stimulation of the in situ isolated muscles did not reveal any major defect in the contractile or fatigue properties (Table VII). These studies examined both the highly aerobic soleus muscle and the mixedfibered gastrocnemius muscle to insure that an effect specific to one fiber type was not occurring. Calculations of mean tension-time units (the average tension multiplied by the time of contraction) in the normal and iron-deficient animals were virtually identical with values of 98.8 and 98.2 for the gastrocnemius and 301 and 299 for the soleus muscle. The lack of any difference in tension-time units between the stimulated muscles rules out such a specificity. Chemical studies carried out on the soleus muscle showed no significant difference between muscle ATP in iron-deficient as compared with $\mathrm{Cl}$ animals at rest $(6.53 \pm 0.39 \mathrm{vs}$. $5.13 \pm 0.75 \mathrm{mM} / \mathrm{kg}, P>0.05)$ and after stimulation $(3.55 \pm 0.35$ vs. $3.25 \pm 0.55 \mathrm{mM} / \mathrm{kg}, P>0.05)$. Likewise, muscle creatine phosphate after stimulation was similar in iron-deficient and control animals $(3.29 \pm 0.90 \mathrm{vs}$. $3.04 \pm 1.23 \mathrm{mM} / \mathrm{kg}$ ), but a difference appeared to exist between resting values of $6.15 \pm 0.18$ in iron-deficient vs. $10.75 \pm 1.46 \mathrm{mM} / \mathrm{kg}$ in $\mathrm{C} 2, P<0.01$. Blood lactate levels changed $<0.5 \mathrm{mM}$ in all animals stimulated, presumably because of the small mass of muscle

TABLE V

Effect of Lactic Acid Infusion in Normal Rats on Running Time (Fast Run)

\begin{tabular}{|c|c|c|c|c|c|c|}
\hline & \multirow[b]{2}{*}{ Animals } & \multirow[b]{2}{*}{ Running time } & \multicolumn{4}{|c|}{ Blood values at end of run } \\
\hline & & & Lactate & $\mathrm{pH}$ & $\mathrm{PO}_{2}$ & $\mathrm{PCO}_{2}$ \\
\hline & & $\min$ & $m M$ & & torr & torr \\
\hline \multicolumn{7}{|l|}{ Group 1* } \\
\hline Base-line run & $\mathrm{Cl}$ & $18.00 \pm 1.4$ & $11.55 \pm 0.79$ & $7.204 \pm 0.028$ & $24.9 \pm 2.24$ & $37.5 \pm 1.64$ \\
\hline Lactate run & & $7.00 \pm 1.4 \S$ & $18.37 \pm 1.56^{\prime \prime}$ & $7.000 \pm 0.054^{\prime \prime}$ & $23.6 \pm 2.01$ & $39.5 \pm 2.80$ \\
\hline \multicolumn{7}{|l|}{ Group $2 \ddagger$} \\
\hline Base-line run & $\mathrm{Cl}$ & $19.90 \pm 1.4$ & $10.58 \pm 0.81$ & $7.263 \pm 0.027$ & $26.3 \pm 3.20$ & $36.9 \pm 0.32$ \\
\hline Lactate + bicarbonate run & & $7.95 \pm 1.5 \S$ & $27.40 \pm 1.44 \S$ & $7.435 \pm 0.027^{\prime \prime}$ & $26.3 \pm 1.60$ & $34.0 \pm 4.80$ \\
\hline
\end{tabular}

* These six animals had a mean hemoglobin before exchange transfusion of $11.8 \pm 0.5 \mathrm{~g} / \mathrm{dl}$ and were exchanged to $10.0 \pm 0.1 \mathrm{~g} / \mathrm{dl}$. \$ These six animals had a mean hemoglobin concentration of $13.5 \pm 0.3 \mathrm{~g} / \mathrm{dl}$ before and $10.0 \pm 0.1 \mathrm{~g} / \mathrm{dl}$ after exchange transfusion.

$\S$ Difference between iron-deficient and control animals significant to $P<0.001$.

" Difference between iron-deficient and control animals significant to $P<0.05$. 
TABLE VI

Effect of Bicarbonate Infusion on Running Times of Six Iron-Deficient Rats(Slow Run)

\begin{tabular}{lccccc}
\hline & \multirow{2}{*}{$\begin{array}{c}\text { Running } \\
\text { time }\end{array}$} & Lactate & $\mathrm{pH}$ & $\mathrm{PO}_{2}$ & $\mathrm{PCO}_{2}$ \\
\cline { 3 - 6 } & $\min$ & $\mathrm{mM}$ & & torr & torr \\
& & & & & \\
& & & & & \\
Base-line & $12.3 \pm 1.5$ & $15.52 \pm 0.78$ & $7.04 \pm 0.04$ & $46.4 \pm 4.5$ & $34.1 \pm 2.6$ \\
Bicarbonate & $12.6 \pm 0.6$ & $18.05 \pm 1.95$ & $7.47 \pm 0.04^{*}$ & $33.5 \pm 4.1$ & $35.2 \pm 2.2$ \\
\hline
\end{tabular}

* Significance between bicarbonate and base-line runs of $P<0.001$.

contracting. Muscle lactate of control animals was increased from $1.83 \pm 0.43$ resting to $11.67 \pm 4.31 \mathrm{mM}$ with stimulated, whereas muscle lactate of iron-deficient animals increased from $2.79 \pm 0.6$ to $5.7 \pm 1.11 \mathrm{mM}$. The greater lactate concentration of the soleus muscle in exercising controls as compared with that of irondeficient animals $(P>0.05)$ was unexplained, but neither reached the high levels seen in the running animal.

\section{DISCUSSION}

Iron deficiency causes depletion of iron-containing cellular compounds (17-20). The degree of this depletion is a function of a number of factors including

TABLE VII

Summary of Contractile Data for the Stimulated Muscle of Normal and Iron-Deficient Rats*

\begin{tabular}{|c|c|c|}
\hline & Control (Cl) & Iron-deficient \\
\hline \multicolumn{3}{|l|}{ Group 1} \\
\hline \multicolumn{3}{|l|}{$\begin{array}{l}\text { Gastrocnemius } \\
\text { stimulation }\end{array}$} \\
\hline Peak tension, $g$ & $262.50 \pm 22.40$ & $212.50 \pm 11.60$ \\
\hline Peak tension, $g / g$ & $176.90 \pm 13.90$ & $197.40 \pm 6.82$ \\
\hline $\begin{array}{l}\text { Time to } 50 \% \text { of peak } \\
\text { tension, } \min \end{array}$ & $0.75 \pm 0.05$ & $0.93 \pm 0.07 \ddagger$ \\
\hline $\begin{array}{l}\text { Time to } 25 \% \text { peak } \\
\text { tension, } \min \end{array}$ & $3.86 \pm 1.78$ & $2.80 \pm 0.78$ \\
\hline \multicolumn{3}{|l|}{ Group 2} \\
\hline \multicolumn{3}{|l|}{ Soleus stimulation } \\
\hline $\begin{array}{l}\text { Peak tension, } g \\
\text { Tensions after } 30\end{array}$ & $13.00 \pm 0.84$ & $10.30 \pm 0.63 \ddagger$ \\
\hline $\min , g$ & $6.90 \pm 0.04$ & $9.80 \pm 0.21 \ddagger$ \\
\hline
\end{tabular}

* The six animals in group 1 had a mean hemoglobin of $13.8 \pm 0.6 \mathrm{~g} / \mathrm{dl}$ before and $10.1 \pm 0.1$ after exchange transfusion. The six iron-deficient animals in group 1 had a mean hemoglobin of $5.2 \pm 0.2$ before and $9.9 \pm 0.1$ after exchange. Group 2 normal animals had a mean hemoglobin of $13.5 \pm 0.3$ before and 10.1 \pm 0.1 after exchange. Group 2 iron-deficient animals had a mean hemoglobin of $5.6 \pm 0.2$ before and $9.9 \pm 0.1$ after exchange.

$\ddagger$ Difference between iron-deficient and control animals significant to $P<0.05$. age of the animal and severity and duration of the deficiency (21). In a previous study (1) the feeding of an iron-deficient diet to 4-wk-old rats for 1 mo reduced blood hemoglobin concentration and muscle myoglobin to between 40 and $50 \%$ of basal levels, whereas cytochrome $a, b$, and $c$ and $\alpha$-glycerophosphate oxidase activities were reduced to 50 and $60 \%$. In this study a similar degree of depletion was produced. It was felt advisable to have two types of control animals: $\mathrm{Cl}$ animals were on a normal diet containing abundant iron, whereas C2 animals were on the identical diet used for iron-deficient animals but were given parenteral iron weekly. Although some minor differences were observed between these two controls, probably related to the lesser amount of available iron in the C2 animal, these were insignificant when compared with the differences between controls and iron-deficient animals. An additional feature of the experimental model was the use of exchange transfusion to eliminate the effects of anemia. It was found that tissue iron dysfunction persisted for at least 1 wk after the hemoglobin of iron-deficient animals had been raised by exchange transfusion (1).

Two intensities of physical activity were employed to examine work performance. The fast run consisted of an incremental work load designed to test maximal work capacity. Even control animals were unable to continue much beyond $20 \mathrm{~min}$, and the iron-deficient nonanemic animal usually began to rest intermittently by the end of the 2 nd min. The slow run was an attempt to determine that level of activity at which control animals and some iron-deficient animals might attain an equilibrium state, in which energy production could be sustained for long periods at a level adequate for the work output required. This permitted a separation of iron-deficient animals into those with severe vs. mild impairment in work capacity.

A marked curtailment in work performance by iron-deficient animals had been previously demonstrated, and it was proposed that the critical feature was a decrease in the mitochondrial enzyme system, $\alpha$-glycerophosphate oxidase (1). Evidence was circumstantial in that the concentration of the enzyme in the muscle paralleled changes in work performance. Other 
iron compounds in muscle such as myoglobin and cytochromes were excluded as a cause of muscle dysfunction because their concentrations, although decreased, did not improve with iron therapy during the time required to normalize running. The relationship between the $\alpha$-glycerophosphate oxidase system and work performance was documented in a somewhat different way in this study. Iron-deficient animals with the same degree of anemia before exchange transfusion, after their hemoglobin was adjusted to $10 \mathrm{~g} / \mathrm{dl}$, were segregated on the basis of their running time. A much lower $\alpha$-glycerophosphate oxidase activity was found in those animals with poor running times as compared with iron-deficient animals who could continue the slow run beyond $20 \mathrm{~min}(P<0.001)$. Thus, $\alpha$-glycerophosphate oxidase deficiency is either the cause of the functional abnormality or is closely coupled with it. On the other hand, the dissociation between the preexchange hemoglobin concentration and work performance indicates that hemoglobin concentration per se is an unreliable indicator of the severity of tissue iron deficiency.

The metabolic effects of iron deficiency within the skeletal muscle cell are undoubtedly complex. Oxidative phosphorylation is decreased along the pyruvate, malate, succinate, and $\alpha$-glycerophosphate oxidase pathways (1). $\alpha$-glycerophosphate oxidase itself has two effects, one involving oxidative phosphorylation within the mitochondria and the other a coupling with cytoplasmic NADH to regenerate cytoplasmic NAD (22). Excess lactate could then result from conversion of pyruvate to lactate as a means of regenerating NAD and could also come from impaired mitochondrial phosphorylation with accumulation of pyruvate. Because the metabolic reserve of the cell is not known, one can only speculate that the recovery of $\alpha$-glycerophosphate activity makes it possible for the muscle to function at maximum work capacity despite other residual mitochondria deficiencies.

The relationship between lactic acidosis and the cessation of running was impressive. By employing the slow run it was possible to select some irondeficient animals who could run over extended periods of time and who did not develop high blood lactate concentrations, whereas other animals had a progressive elevation and discontinued work at a lactate level of about $18 \mathrm{mmol}$, a level similar to that found in iron-deficient animals in the fast run and to normal animals infused with lactate at a point when they stopped running. Although this strongly suggested that lactic acidosis forced a discontinuation of activity, other possibilities needed to be considered. A decrease in oxygen supply as a result of anemia (23) or of decreased cardiac output (24) can produce lactic acidosis, but the former was excluded by exchange transfusion and the latter was excluded by blood gas studies. In fact, there was a considerable increase in the in vivo oxygen tension of arterial and venous blood, largely attributable to the lower $\mathrm{pH}$ (Bohr effect) in the iron-deficient animal. Other nutrients required for normal muscle metabolism, including blood glucose and free fatty acids, as well as muscle glycogen, appeared adequate at the time that activity ceased, and at any rate a deficiency would be expected to reduce blood lactate (25).

One way of insuring adequate substrate and at the same time limiting the accumulation of lactic acid was by the use of an in situ muscle preparation. Here blood flow to the working muscle could be maximally increased, while the production of lactate within the single muscle would be small compared with the disposal capacity of the body. In this setting both soleus and gastrocnemius muscles of the irondeficient animals performed as well as those of controls. Such results would seem to exclude structural abnormalities of the muscle as a cause of impaired performance and would still be consistent with a hypothesis that lactic acidosis was required to impair muscle work. Lactate concentrations in these muscles after stimulation were less than those observed with treadmill exercise, perhaps because of a lower work requirement but also because of the greater gradient between muscle and blood in the in situ muscle preparation.

One of the questions raised by these studies is the way in which lactic acidosis impairs work performance. Muscles are known to function well at an intracellular $\mathrm{pH}$ calculated to be as low as 6.4 (26). Because the maintenance of a normal blood $\mathrm{pH}$ did not improve running time either in the iron-deficient or normal animals infused with lactate, some effect of lactate itself rather than acidosis was likely responsible. Admittedly, blood rather than muscle $\mathrm{pH}$ was monitored, but the similar impairment of work performance with infusion of lactate into normal animals along with the rapid escape of hydrogen ions from muscles (27) directs suspicion to the lactate concentration.

This is not to say that severe acidosis created by lactate excess is without effect. Certainly there is ample evidence of its ability to impair cardiac function (24), to impair vasomotor regulation (28), and to impair the catabolism of lactate itself in the liver (29). Our observation, however, differs from the usual descriptions of lactic acidosis in that it occurs in the face of increased physical activity, and focuses rather on striate muscle performance.

At the present time the clinical implications of these observations are conjectural. It is not known whether humans with chronic iron deficiency have limitations in work performance based on a similar tissue abnormality. Although it may be difficult in man to separate the known decrease in work performance 
associated with anemia (30) from a similar tissue lesion, divergences may occur between the effect of iron deficiency on hemoglobin concentration as compared with its effect on tissue enzymes. It is also possible that iron deficiency may contribute to other types of lactic acidosis described in man (24).

\section{ACKNOWLEDGMENT}

This work was supported in part by National Institutes of Health grants HL-06242, HL-18527, HL-12174, RCDA HL-00182, G.M-23006, HD-05961, and HD-02274.

\section{REFERENCES}

1. Finch, C. A., L. R. Miller, A. R. Inamdar, R. Person, K. Seiler, and B. Mackler. 1976. Iron deficiency in the rat. Physiological and biochemical studies of muscle dysfunction. J. Clin. Invest. 58: 447-453.

2. Wranne, B., and R. D. Woodson. 1973. A graded treadmill test for rats: maximal work performance in normal and anemic animals. J. Appl. Physiol. 34: 732-735.

3. Passonneau, J. V., and V. R. Lauderdale. 1974. A comparison of three methods of glycogen measurement in tissues. Anal. Biochem. 60: 405-412.

4. Lo, S., J. C. Russell, and A. W. Taylor. 1970. Determination of glycogen in small tissue samples. J. Appl. Physiol. 28: 234-236.

5. Hohorst, H-J. 1963. L-(+)-lactate. Determination with lactic dehydrogenase and DPN. In Methods of Enzymatic Analysis. H-U. Bergmeyer, editor. Academic Press, New York. 1st edition. 266-270.

6. Wollenberger, A., O. Ristau, and G. Schoffa. 1960. Eine einfache Technik der extrem schnellen Abkeuhlung grosser Gewebestueke. Pfluegers Archiv Gesamte Physiol. Menschen Tiere. 279: 399-412.

7. Wieland, O. 1975. Eine enzymatische Method zur Bestimmung von Glycerin. Biochem. Z. 329: 313-317.

8. Lowry, O. H., and J. V. Passonneau. 1972. A Flexible System of Enzymatic Analysis. Academic Press, Inc., New York.

9. The International Committee for Standardization in Hematology. 1971. Proposed recommendations for measurement of serum iron in human blood. Blood. 37: $598-600$.

10. Cook, J. D. 1970. An evaluation of absorption methods for measurement of plasma iron-binding capacity. J. Lab. Clin. Med. 76: 497-506.

11. Dole, V. P. 1956. A relation between non-esterified fatty acids in plasma and the metabolism of glucose. J. Clin. Invest. 35: 150-154.

12. Bücher, T., R. Czok, W. Lamprecht, and E. Latzko. 1963. Pyruvate. In Methods of Enzymatic Analysis. H-U. Bergmeyer, editor. Academic Press, Inc., New York. 1st edition. 253-259.
13. Lenfant, C., P. Ways, C. Aucutt, and J. Cruz. 1969. Effect of chronic hypoxic hypoxia on the $\mathrm{O}_{2}-\mathrm{Hb}$ dissociation curve and respiratory gas transport in man. Respir. Physiol. 7: 7-29.

14. Snedecor, G. W., and W. G. Cochran. 1967. Statistical Methods. The Iowa State University Press, Ames, Iowa. 6th edition.

15. Altland, P. D., H. F. Brubach, M. G. Parker, and B. Highman. 1967. Blood gases and acid-base values of unanesthetized rats exposed to hypoxia. Am. J. Physiol. 212: $142-148$.

16. Pepelko, W. E. 1972. Interaction of chronic hypoxia and hypercapnia upon blood gases and acid base status. Proc. Soc. Exp. Biol. Med. 140: 628-632.

17. Dallman, P. R. 1974. Tissue effects of iron deficiency. In Iron in Biochemistry and Medicine. A. Jacobs and M. Worwood, editors. Academic Press, Inc., New York. 437-475.

18. Beutler, E., and R. K. Blaisdell. 1960. Iron enzymes in iron deficiency. V. Succinic dehydrogenase in rat liver, kidney, heart. Blood. 15: 30-35.

19. Bailey-Wood, R., L. N. Blayney, J. R. Muir, and A. Jacobs. 1975. The effects of iron deficiency on rat liver enzymes. Br. J. Exp. Pathol. 56: 193-198.

20. Edgerton, V. R., S. L. Bryant, C. A. Gillespie, and G. W. Gardner. 1972. Iron deficiency anemia and physical performance and activity of rats. J. Nutr. 102: 381-400.

21. Koziol, B. J., Y. Ohira, D. R. Simpson, and V. R. Edgerton. 1978. Biochemical skeletal muscle and hematological profiles of moderate and severely iron deficient and anemic adult rats. J. Nutr. 108: 1306-1314.

22. Lehninger, A. L. 1977. Biochemistry. Worth Publishers, New York.

23. Cain, S. M. 1965. Appearance of excess lactate in anesthetized dogs during anemic and hypoxic hypoxia. Am. J. Physiol. 209: 604-610.

24. Cohen, R. D., and H. F. Woods. 1976. Clinical and Biochemical Aspects of Lactic Acidosis. Blackwell Scientific Publications Ltd., Oxford.

25. Issekutz, B., Jr. 1978. Role of beta-adrenergic receptors in mobilization of energy sources in exercising dogs. J. Appl. Physiol. 44: 869-876.

26. Poole-Wilson, P. A., and I. R. Cameron. 1975. Intracellular $\mathrm{pH}$ and $\mathrm{K}^{+}$of cardiac and skeletal muscle in acidosis and alkalosis. Am. J. Phyisol. 229: 1305-1310.

27. Schumer, W. 1966. Lactic acid as a factor in the production of irreversibility in oligohaemic shock. Nature (Lond.). 212: 1210-1212.

28. Iles, R. A., P. G. Baron, and R. D. Cohen. 1978. Mechanism of the effect of varying $\mathrm{pCO}_{2}$ on gluconeogenesis from lactate in the perfused rat liver. Clin. Sci. Mol. Med. 55: $183-188$

29. Sahlin, K., A. Alvestrand, R. Brandt, and E. Hultman. 1978. Intracellular $\mathrm{pH}$ and bicarbonate concentration in human muscle during recovery from exercise. J. Appl. Physiol. 45: 474-480.

30. Viteri, F. E., and B. Torun. 1974. Anaemia and physical work capacity. Clin. Haematol. 3: 609-626. 